\title{
ODNOS RELIGIOZNOSTI I SEKSUALNOSTI ADOLESCENTICA - IMAJU LI RODITELJI POSREDUJUĆU ULOGU U TOJ VEZI?
}

Izvorni znanstveni članak Primljeno: Srpanj, 2015. Prihvaćeno: Rujan, 2015. UDK: 27:613.88-055.25 D0I: $10.3935 /$ ljsr.v22i2.88

Linda Rajhvajn Bulat $^{1}$

Pravni fakultet Sveučilišta u Zagrebu

Studijski centar socijalnog rada

\section{SAŽETAK}

Cilj rada je ispitati povezanost religioznosti adolescentica s njihovim seksualnim ponašanjem i doživljavanjem te kakvu ulogu u toj vezi imaju odnos djevojaka s roditeljima te komunikacija s njima.

U istraživanju je sudjelovalo 560 učenica prvih i trećih razreda srednjih škola Grada Zagreba i Zagrebačke županije. Varijable značajne za ovaj rad mjerene su Upitnikom seksualnosti (seksualno ponašanje, namjera upuštanja u spolne odnose u idućih godinu dana te misli i osjećaji prema upuštanju u spolne odnose u tom razdoblju), tvrdnjama koje se odnose na religioznost sudionica, subskalom Odnosa s roditeljima Marshovog upitnika samoopisivanja II, Skalom roditeljskog i vršnjačkog odobravanja seksualnog ponašanja te Upitnikom o komunikaciji adolescenta s roditeljima.

Rezultati potvrđuju kako je religioznost djevojaka značajno povezana s njihovim seksualnim ponašanjem i doživljavanjem, pri čemu se najreligioznije djevojke

Ključne riječi:

adolescentice, seksualno ponašanje, religioznost, roditelji, komunikacija.

1 Dr. sc. Linda Rajhvajn Bulat, psihologinja, e-mail: lindarajhvajn@net.hr

2 Ovaj rad dijelom je financiran od strane fakultetskog projekta Novi hrvatski pravni sustav za 2013. godinu, Pravnog fakulteta Sveučilišta u Zagrebu 
ističu manjim seksualnim iskustvom te manjom motivacijom za upuštanje u spolne odnose u idućih dvanaest mjeseci. Povezanost religioznosti i seksualnosti je veća kod starijih adolescentica. Također, pokazalo se kako su posredne poruke koje im roditelji šalju o seksualnosti značajan medijator u vezi između religioznosti i seksualnosti djevojaka. Kod učenica prvih razreda srednje škole u toj je vezi značajan medijator i odnos s roditeljima, dok je kod učenica trećih razreda to slučaj za odobravanje seksualnog ponašanja adolescentice od strane roditelja.

\section{UVOD}

Spolno ponašanje mladih u posljednje je vrijeme u središtu pažnje hrvatske javnosti, a ovim radom želi se pridonijeti boljem razumijevanju seksualnosti djevojaka te kakvu ulogu u njoj ima religioznost adolescentica i neka obilježja njihovog odnosa s roditeljima.

Prema svjetskoj zdravstvenoj organizaciji (WHO, 2004.), seksualnost je središnji aspekt ljudskih bića, koji uključuje eroticizam, intimnost, užitak, reprodukciju i osobni spolni identitet. Manifestacije seksualnosti ne odnose se samo na seksualna ponašanja, već i na želje, čežnje, maštanja, stavove, uloge i odnose. Seksualnost adolescenata je više od prvog spolnog odnosa ili »seksualnih rizika«, ona podrazumijeva osjećaje prema sebi, samoprocjene, stavove i ponašanja (Graber i Sontag, 2006.). U skladu s tim, u radu će se naglasak staviti na različite pokazatelje seksualnosti, koji se odnose i na seksualno ponašanje i na motivaciju za upuštanje u spolne odnose.

\section{Obilježja seksualnosti i učestalost seksualnog ponašanja adolescenata}

Rezultati istraživanja provedenih u Sjedinjenim Američkim Državama pokazuju kako gotovo polovica srednjoškolaca ima iskustvo spolnih odnosa (CDC, 2014.; Kirby i Lepore, 2007.), a prema podacima Krauss i sur. (2012.) dobivenim na srednjoškolcima šest država Europske unije, u prosjeku je 49,5\% mladih stupilo u spolne odnose. Što se tiče istraživanja provedenih u Hrvatskoj, rezultati su raznoliki, ali ukazuju na manju zastupljenost seksualno iskusnih adolescenata nego što je slučaj u svijetu. Bernik i Hlebec (2005.) navode kako RH u odnosu na ostale post-socijalističke države, pripada u kategoriju zemalja s niskim udjelom seksualno iskusnih adolescenata. Tako se postoci hrvatskih srednjoškolaca koji su imali spolni odnos 
kreće od 26,7\% (Bernik i Hlebec, 2005.) do 39-40\% (Ajduković, Ručević i Šincek, 2008.; Hodžić i Bijelić, 2003.), no velike razlike u dobivenim postocima barem se djelomično mogu pripisati vrlo različitim metodološkim pristupima.

Kada je riječ o dobi stupanja u spolne odnose, u istraživanju Božičević i sur. (2006.) na reprezentativnom nacionalnom uzorku mladih od 18 do 24 godine, prosječna dob stupanja u spolne odnose bila je 17,2 godine za mladiće i 17,6 za djevojke, a slična dob dobivena je i u novijim domaćim istraživanjima Dijanić i sur. (2014.) te Vranješ, Džepina i Juhović Markus (2011.). U usporedbi s drugim državama, Ross i sur. (2004.) navode da je trećina ili više 15-godišnjaka u Engleskoj, Škotskoj i Ukrajini imala iskustvo spolnog odnosa, dok je to slučaj za otprilike petinu mladih iz Hrvatske, Španjolske, Poljske, Litve, Latvije, Estonije, Češke, Mađarske i Makedonije. Unatoč tome, u domaćim medijima često se može čuti kako i u Hrvatskoj postoji »europski trend« sve ranijeg stupanja u spolne odnose mladih, a na to su, donekle, ukazala i neka istraživanja. Tako su Kuzman, Pavić Šimetin i Pejnović Franelić (2007.) na nacionalnom uzorku učenika prvih razreda srednje škole pokazali da je spolno aktivno $28,6 \%$ mladića i $16,5 \%$ djevojaka, dok Dabo i sur. (2008.) govore o $29,6 \%$ seksualno iskusnih riječkih šesnaestogodišnjaka (33,4\% mladića i 26,6\% djevojaka). Druga istraživanja navode kako srednjoškolci najčešće prije šesnaeste godine stupe u spolni odnos (Bernik i Hlebec, 2005.; Hodžić i Bijelić, 2003.), no pritom je vjerojatno riječ samo o seksualno iskusnim srednjoškolcima pa je stvarna prosječna dob ulaska u spolne odnose zapravo veća.

Velik broj istraživanja koja se bave seksualnošću adolescenata govori o vaginalnim spolnim odnosima, dok se zanemaruju ostale seksualne aktivnosti, koje najčešće prethode spolnim odnosima ili ih prate istovremeno. Prije prvog vaginalnog spolnog odnosa, mnogi mladi upuste se u druge aktivnosti, kao što su masturbacija s partnerom, oralni i analni spolni odnos (Schuster, Bell i Kanouse, 1996.). U istraživanju Halpern-Felsher i sur. (2005.) pokazalo se da više petnaestogodišnjaka ima iskustvo i/ili namjerava imati oralni seks, a ne vaginalni. Stoga su u istraživanju predstavljenom u ovom radu istraženi različiti oblici spolnih odnosa i seksualnog ponašanja te se na taj način nastojalo doprinijeti širem sagledavanju seksualnosti adolescenata.

\section{Povezanost seksualnog ponašanja i religioznosti adolescenata}

Seksualno ponašanje mlade osobe određeno je širom okolinom u kojoj ona živi, gdje veliku važnost imaju obitelj, vršnjaci i škola. Seksualnost adolescenata se $\mathrm{u}$ istraživanjima često dovodila u vezu s religioznošću mladih i njihovih roditelja, a 
istraživanja koja se bave tom problematikom dala su i najdosljednije rezultate. Veća religioznost povezana je s odgađanjem seksualne aktivnosti i manjim brojem seksualnih partnera u adolescenciji (npr. Burdette i Hill, 2009.; Haglund i Fehring, 2010;; Hull i sur., 2011.). Također, adolescenti koji ranije stupaju u spolne odnose češće odrastaju u manje religioznim obiteljima (Landor i sur., 2011.; Manlove i sur., 2006.).

U longitudinalnom istraživanju Manlove i sur. (2008.) ranija i trenutna obiteljska religioznost bila je i direktno i indirektno povezana sa seksualnom aktivnošću sedamnaestogodišnjaka. Medijatori su bili obiteljska kohezija (nadzor od strane roditelja, kvaliteta odnosa između roditelja i adolescenta te obiteljske dnevne aktivnosti) i negativna ponašanja vršnjaka (konzumacija alkohola, psihoaktivnih tvari i cigareta, uključenost u bande, bježanje iz škole, odnosno »markiranje«). Veća obiteljska religioznost indirektno je povezana s manjim brojem seksualnih partnera i dosljednom uporabom kontracepcije, a medijator u tom odnosu bila je kasnija dob prvog spolnog odnosa, pozitivniji vršnjački kontekst (odlaženje u crkvu, uključivanje u izvannastavne aktivnosti, namjera za nastavkom školovanja i volonterstvo) te veći roditeljski nadzor i znanje o djetetovom ponašanju. $U$ istraživanju Burdette i Hill (2009.), od različitih elemenata religijske uključenosti, istaknutost religije (važnost religije u svakodnevnom životu i odlučivanju adolescenta) pokazala se naročito povezanom s odgađanjem seksualnog ponašanja adolescenta. $U$ istom je istraživanju često odlaženje u crkvu bilo povezano s odgađanjem seksualnog diranja i prvog spolnog odnosa, ali ne i s oralnim spolnim odnosom.

Kako su u dosadašnjim istraživanjima od obiteljskih varijabli značajnih za razumijevanje odnosa između religioznosti i seksualnog ponašanja adolescenata najčešće ispitivani odnos s roditeljima i nadzor roditelja nad djecom, u ovom će radu obiteljski kontekst biti upotpunjen varijablama roditeljskog odobravanja seksualnog ponašanja njihove djece te komunikacije između roditelja i djece. Pritom je poseban naglasak stavljen na posrednu komunikaciju roditelja o seksualnosti, koja je često zaobilažena u literaturi, a predstavlja snažan izvor prenošenja poruka djeci od strane roditelja.

lako su u dosadašnjem tekstu prikazani rezultati za mlade neovisno o spolu, u ovom radu će se naglasak staviti na djevojke. Istraživanja su pokazala kako je religioznost značajno više povezana sa seksualnim ponašanjem djevojaka nego mladića (Rostosky, Regnerus i Wright, 2003.; Landor i sur., 2011.). Slično tome, roditeljski utjecaji i ponašanje imaju veći i dugotrajniji utjecaj na seksualni život njihovih kćeri nego sinova (Baumeister i Blackhart, 2007.; Landor i sur., 2011.).

Cilj rada je ispitati kakva je povezanost religioznosti adolescentica s njihovim seksualnim ponašanjem i doživljavanjem te kakvu ulogu u toj vezi imaju odnos djevojaka s roditeljima te komunikacija s njima. S obzirom na to, postavljena su dva problema istraživanja:

\section{8 članci}


1. Provjeriti povezanost religioznosti mlađih i starijih adolescentica s različitim pokazateljima njihovog seksualnog ponašanja i doživljavanja.

2. Provjeriti medijacijski učinak roditeljskih varijabli na povezanost između religioznosti i seksualnosti adolescentica.

\section{METODA}

\section{Sudionici}

U istraživanju je korišten dvoetapni stratificirani slučajni uzorak, pri čemu se koristila proporcionalna stratifikacija škola s obzirom na vrstu škole (gimnazija/ strukovna) i županiju koju predstavlja (Zagrebačka/Grad Zagreb). U prvoj etapi uzorkovanja su, radi ekonomičnosti provođenja istraživanja, odabrane samo one škole koje imaju preko $50 \%$ učenica (isključene su škole u kojima prevladavaju muški učenici) i one sačinjavaju okvir uzorkovanja. U svakoj (jednostavnim slučajem) odabranoj školi po slučaju su odabrana dva prva i dva treća razreda, što predstavlja klaster uzorak svih učenica u određenom razredu.

Podaci su obrađeni na 560 učenica prvih $(\mathrm{N}=277,49,5 \%)$ i trećih razreda ( $\mathrm{N}=$ $283,50,5 \%)$, odnosno djevojaka u razdoblju srednje i kasne adolescencije. Prosječna dob sudionica učenica prvih razreda kretala se od 15 do 16,5 godina $(M=15,56$, $\mathrm{SD}=0,38)$, a učenica trećih razreda od 17 do 19 godina $(\mathrm{M}=17,55, \mathrm{SD}=0,40)$. Broj sudionica bio je ravnomjerno raspoređen po vrsti škole - $261(46,6 \%)$ iz gimnazije i 299 (53,4\%) iz strukovnih škola. Vezano za seksualno iskustvo, 53 (19,1\%) učenice prvih razreda i $130(46,4 \%)$ učenica trećih razreda imaju iskustvo vaginalnog spolnog odnosa.

\section{Postupak}

Podaci prikazani u ovom radu dio su većeg seta podataka prikupljenih $u$ istraživanju "Okolinske i osobne odrednice seksualnog ponašanja adolescentica". Postupak prikupljanja podataka bio je u skladu s Etičkim kodeksom istraživanja s djecom (2003.). Prije provođenja istraživanja, dobivena je suglasnost ravnatelja škola, kojima je upućena preporuka Ministarstva znanosti, obrazovanja i sporta te Agencije za odgoj i obrazovanje. Roditelji sudionica su o provedbi istraživanja informirani pismenim putem. Samo prikupljanje podataka odvijalo se grupno, u razredima sudionica, i trajalo je jedan školski sat. Na početku istraživanja učenicama je detaljno objašnjena njegova svrha te su imale mogućnost reći žele li u njemu 
sudjelovati ili ne. Učenice koje nisu bile voljne sudjelovati u istraživanju, priključile su se muškim kolegama iz razreda u radu s predmetnim nastavnikom, u drugoj prostoriji. Prilikom ispunjavanja i predavanja upitnika osigurala se anonimnost $\mathrm{i}$ povjerljivost podataka sudionica.

\section{Instrumentarij}

U istraživanju je korišten upitnik sastavljen od 7 instrumenata, no u ovom radu opisana je operacionalizacija i način mjerenja onih varijabli koje su relevantne za navedene probleme istraživanja.

Seksualnost. Upitnik seksualnosti sastoji se od skupa čestica kojima su Hennessy i sur. (2008.) ispitivali različite aspekte seksualnosti adolescenata. Prvi dio upitnika odnosi se na listu od sedam seksualnih ponašanja različitog intenziteta (iskustvo poljupca jezikom, diranja grudi od strane partnera, diranja ispod struka, iskustvo pružanja oralnog spolnog odnosa, primanja oralnog spolnog odnosa, analnog spolnog odnosa te iskustvo vaginalnog spolnog odnosa). Sudionica za svako ponašanje odgovara je li s njim dosada imala iskustvo ili nije. Ukupni rezultat predstavlja jednostavni zbroj svih seksualnih iskustava. Cronbachov a koeficijent pouzdanosti za ovu subskalu iznosi 0,85 . Ukoliko je sudionica imala vaginalni spolni odnos, od nje se tražilo da navede i dob stupanja u prvi spolni odnos te ukupni broj partnera s kojima je imala tu vrstu odnosa. Misli i osjećaji vezani za stupanje u spolne odnose u idućih godinu dana, drugi dio upitnika, ispitivani su procjenom na skali od 7 stupnjeva za pet parova suprotnih pridjeva (sudionice su procjenjivale koliko bi to iskustvo za njih bilo, na primjer, loše odnosno dobro, glup potez odnosno mudar potez, štetno odnosno korisno). Ukupni rezultat predstavlja zbroj odgovora na svim česticama, pri čemu veći rezultat ukazuje na pozitivnije gledanje na upuštanje u spolne odnose u idućih godinu dana. Cronbachov a koeficijent pouzdanosti ove subskale je 0,91 . Konačno, bihevioralna namjera odnosi se na procjenu namjere održavanja spolnih odnosa u sljedećih godinu dana na skali od 5 stupnjeva (od 1 - sigurno ne do 5 - sigurno da). Ovaj dio skale, u kombinaciji s mislima i osjećajima, predstavlja ispitivanje motivacije sudionica o upuštanju u spolne odnose.

Religioznost. Religioznost djevojaka ispitana je upitnikom sociodemografskih i osobnih podataka, pomoću četiri čestice, preuzete iz upitnika Europskog istraživanja vrijednosti (European Values Study) iz 2008. godine. U ovom istraživanju, značaj vjere u njihovom životu i životu njihovih roditelja, adolescentice su procijenile na skali od 10 stupnjeva (od 1 - potpuno nevažna do 10 - jako važna), dok su na skali od 7 stupnjeva izrazile učestalost izvršavanja propisanih religijskih obveza (za molitvu izvan vjerskog obreda od 1 - svaki dan do 7 - nikada, gotovo 
nikada, a za pohađanje vjerskih obreda od 1 - češće nego jednom tjedno do 7 nikada, gotovo nikada). Ukupni rezultat na skali religioznosti formiran je kao zbroj odgovora na svim česticama. Veći rezultat ukazuje na veću religioznost adolescentice. Cronbachov a koeficijent pouzdanosti skale je 0,85 , a Pearsonovi koeficijenti korelacije između pojedinih čestica su od 0,48 do 0,73.

Odnos s roditeljima. Varijabla odnosa s roditeljima mjerena je istoimenom subskalom Marshovog upitnika samoopisivanja II (Marsh, 1992.). U ovom istraživanju koristila se prilagođena skala od 4 stupnja (od 1 - netočno/uopće me ne opisuje do 4 - točno/u potpunosti me opisuje). Ukupni rezultat određuje se zbrajanjem rezultata na svakoj čestici. Subskala odnosa s roditeljima sastoji se od 8 tvrdnji, pri čemu veći rezultat ukazuje na bolji odnos između roditelja i adolescenta. Cronbachov a koeficijent pouzdanosti je 0,85.

Odobravanje seksualnog ponašanja adolescentice od strane roditelja. Ovo je ponašanje mjereno Skalom roditeljskog i vršnjačkog odobravanja seksualnog ponašanja (Treboux i Busch-Rossnagel, 1990.). U svrhu ovog istraživanja prilagođena verzija skale sastoji se od 12 tvrdnji koje se odnose na 3 stupnja intimnog odnosa (izlazak s dečkom jednom ili dvaput, zaljubljenost/»hodanje» te planiranje udaje), za koje se ispituju procjene odobravanja roditelja (zasebno za oca i majku) i prijatelja, i to za četiri progresivna seksualna ponašanja (ljubljenje, diranje grudi, diranje intimnih dijelova tijela i spolni odnos). Sudionice svoje procjene daju na skali od 4 stupnja (od 1 - jako bi se protivio/la do 4 - odobrio/la bi). Prikazani su rezultati koji se odnose na odobravanje seksualnog ponašanja od strane roditelja, a ukupni rezultat formiran je kao prosjek sume na subskali za majku i sume na subskali za oca (viši rezultat ukazuje na veće odobravanje seksualnog ponašanja). Cronbachov a koeficijent pouzdanosti za ovu skalu iznosi 0,90.

Komunikacija između roditelja i adolescentice. Varijable koje se odnose na komunikaciju s roditeljima mjerene su Upitnikom o komunikaciji adolescenta s roditeljima (Rajhvajn Bulat, 2011.), koji se sastoji od tri dijela: verbalna komunikacija, neugoda (odnosno neverbalna komunikacija tijekom razgovora o seksualnim temama) te posredna komunikacija o seksualnosti, a za ovaj rad su od značaja prva i treća subskala. Ispitivanje verbalne komunikacije između adolescenata i roditelja odnosi se na ispitivanje kvalitete razgovora o 8 različitih sadržajnih područja (npr. suvremena socijalno-zdravstvena pitanja, osobni interesi, generalni problemi, stavovi prema seksualnosti, pitanja i problemi u području seksualnosti) kroz 5 aspekata verbalne komunikacije (učestalost razgovora, roditeljevo prihvaćanje adolescentovog mišljenja, roditeljevo prepoznavanje adolescentove želje za razgovorom, otvorenost razgovora, zadovoljstvo razgovorom). Za svaki aspekt procjena se daje na skali od 7 stupnjeva (npr. od 1 - ne razgovaramo otvoreno o toj temi do 7 - u potpunosti otvoreno razgovaramo o toj temi). Sudionice daju svoje 
odgovore za onog roditelja za kojeg smatraju da s njim imaju bolju/kvalitetniju komunikaciju. Izračunata su dva ukupna rezultata - za verbalnu komunikaciju o općim temama i verbalnu komunikaciju o temama koje se tiču seksualnosti. Veći rezultat ukazuje na kvalitetniju komunikaciju, odnosno veće zadovoljstvo komunikacijom s roditeljem za kojeg je djevojka odgovarala. Za verbalnu komunikaciju o općim temama Cronbachov a koeficijent pouzdanosti je 0,96, a za komunikaciju o seksualnim temama $a=0,97$. Subskalu posredne komunikacije $\mathbf{o}$ seksualnosti čini 8 čestica koje ispituju koliko je sudionica upoznata s različitim aspektima seksualnosti roditelja te kakve posredne poruke o seksualnosti oni prenose kćeri (npr. kako reagiraju kada se na televiziji prikazuju eksplicitne intimne scene). Na postavljena pitanja djevojka treba zaokružiti jedan od tri ili četiri ponuđena odgovora. Ukupni rezultat računa se kao zbroj odgovora na svim česticama, a viši ostvareni rezultat ukazuje na »otvoreniju« posrednu komunikaciju roditelja o seksualnosti. Cronbachov a koeficijent pouzdanosti skale je 0,61 , što je zadovoljavajuće s obzirom na činjenicu da se skala sastoji od osam vrlo različitih čestica, odnosno različitih područja seksualnosti roditelja i ponuđenog različitog broja odgovora na različita pitanja.

\section{Obrada podataka}

Podaci prikupljeni istraživanjem obrađeni su paketom za statističku obradu podataka SPSS 15. U obradi rezultata podaci koji nedostaju zamijenjeni su centralnim vrijednostima koje ostale sudionice postižu na pojedinoj varijabli. Međutim, te zamjene nisu učinjene u slučaju kada sudionica nije dala odgovor na veći broj varijabli u određenoj skali ili upitniku (na primjer, ako je u skali misli i osjećaja vezanih za upuštanje u spolne odnose u idućih godinu dana zaokružila samo jedan broj, a ne broj za svaki par pridjeva od $a$ do $e$ ). Kolmogorov-Smirnovim testom podudarnosti utvrđeno je da distribucije većine varijabli značajno odstupaju od normalne krivulje. Za neke je varijable to očekivano (primjerice, za seksualno ponašanje), a moguće je da je statistička značajnost ovih testova jednim dijelom posljedica razmjerno velikog broja sudionica. Varijable za koje je dobiven značajan K-S-Z nisu normalizirane prije daljnjih postupaka jer se time otežava interpretacija utvrđenih povezanosti među varijablama (Tabachnik i Fidell, 1989.). Pretpostavlja se da prisutna odstupanja neće bitno utjecati na rezultate statističkih postupaka koji zahtijevaju normalitet distribucija jer je utvrđeno da standardni postupci koji zahtijevaju normalitet distribucija daju neprihvatljive rezultate samo u slučaju kada podaci sugeriraju da su pretpostavke parametrijske statistike ekstremno narušene. U drugim slučajevima, iako distribucije odstupaju od normalnih, ovi postupci daju

\section{2 članci}


prihvatljive rezultate (Aron i Aron, 1994.), naročito kada su krivulje nagnute u istom smjeru. Ukoliko distribucije rezultata nisu asimetrične u istom smjeru, dobivene korelacije između takvih varijabli mogu biti niže, odnosno u zaključivanju smo izloženi beta pogrešci (pogrešci tipa 2).

Dok je na prvo istraživačko pitanje odgovor dobiven putem Pearsonovih koeficijenata korelacije, kako bi se provjerilo posreduju li roditeljske varijable u odnosu religioznosti i seksualnosti djevojaka, proveden je niz hijerarhijskih regresijskih analiza (HRA). U prvi korak HRA stavljena je religioznost, u drugi odnos s roditeljima, odobravanje seksualnog ponašanja adolescentica od strane roditelja, verbalna komunikacija adolescentica s roditeljima o općim i seksualnim temama te posredna komunikacija roditelja o seksualnosti roditeljske varijable, dok su kriteriji bili varijable seksualnosti. Za značajne roditeljske varijable dodatno je provjeravano jesu li one statistički značajni medijatori između pojedine prediktorske varijable i kriterija. Kako bi se provjerilo koje od značajnih roditeljskih varijabli imaju medijacijski učinak na vezu između religioznosti i pojedinog kriterija, izračunate su dodatne RA (prema naputcima Barona i Kennyja iz 1986.) te u slučaju zadovoljavanja zadanih kriterija, Sobel testom je provjeravana značajnost medijacije za pojedinu posredujuću varijablu i pojedini kriterij (Preacher i Leornadelli, 2003.).

\section{REZULTATI}

U Tablici 1 prikazani su deskriptivni podaci svih varijabli (za cijeli uzorak te zasebno za učenice prvih i učenice trećih razreda). Kao što se može vidjeti, nema statistički značajne razlike u ukupnoj religioznosti mlađih i starijih djevojaka, ali mlađe djevojke nešto češće prisustvuju vjerskim obredima. Nadalje, očekivano su manje seksualno iskusne mlađe djevojke, a starije djevojke imaju i veću motivaciju stupanja u spolne odnose (veću bihevioralnu namjeru i pozitivnije emocije prema upuštanju u spolne odnose u idućih 12 mjeseci). Osim toga, i sami roditelji adolescentica više odobravaju seksualno ponašanje starijih adolescentica te one percipiraju više posrednih poruka koje roditelji šalju vezano za seksualnost. Uslijed navedenih razlika, u svrhu dobivanja odgovora na preostale istraživačke probleme, sve analize rađene su odvojeno za starije i mlađe djevojke. 
Ljetopis socijalnog rada 2015., 22 (3), 415-436 str.

Tablica 1. Deskriptivna statistika i razlika između mlađih i starijih učenicama u svim varijablama korištenim u istraživanju

\begin{tabular}{|c|c|c|c|c|c|c|c|c|c|c|c|}
\hline \multirow{2}{*}{ Varijabla } & \multicolumn{4}{|c|}{ Cijeli uzorak } & \multicolumn{3}{|c|}{ 1. razred } & \multicolumn{3}{|c|}{ 3. razred } & \multirow{2}{*}{$t$} \\
\hline & $\mathrm{N}$ & $M$ & SD & TR & $\mathrm{N}$ & $M$ & SD & $\mathrm{N}$ & $M$ & SD & \\
\hline $\begin{array}{l}\text { Značaj vjere za } \\
\text { adolescenticu }\end{array}$ & 560 & 6,52 & 2,68 & $1-10$ & 277 & 6,58 & 2,65 & 283 & 6,46 & 2,72 & 0,553 \\
\hline $\begin{array}{l}\text { Značaj vjere za } \\
\text { roditelje }\end{array}$ & 560 & 6,50 & 2,66 & $1-10$ & 277 & 6,62 & 2,61 & 283 & 6,38 & 2,71 & 1,097 \\
\hline Učestalost molitve & 560 & 4,85 & 2,12 & $1-7$ & 277 & 4,81 & 2,05 & 283 & 4,89 & 2,19 & $-0,476$ \\
\hline $\begin{array}{l}\text { Učestalost odlaska } \\
\text { na vjerske obrede }\end{array}$ & 560 & 4,31 & 1,70 & $1-7$ & 277 & 4,46 & 1,62 & 283 & 4,16 & 1,76 & $2,091^{*}$ \\
\hline $\begin{array}{l}\text { Religioznost - } \\
\text { ukupno }\end{array}$ & 560 & 22,17 & 7,76 & $4-34$ & 277 & 22,47 & 7,31 & 283 & 21,88 & 8,18 & 0,893 \\
\hline $\begin{array}{l}\text { Odnos s } \\
\text { roditeljima }\end{array}$ & 560 & 25,43 & 4,39 & $8-32$ & 277 & 25,46 & 4,39 & 283 & 25,40 & 4,39 & 0,160 \\
\hline $\begin{array}{l}\text { Odobravanje } \\
\text { roditelja }\end{array}$ & 555 & 28,67 & 6,18 & $12-48$ & 274 & 27,40 & 6,28 & 281 & 29,91 & 5,83 & $-4,873 * * *$ \\
\hline VK - opće teme & 552 & 27,85 & 5,53 & $5-35$ & 272 & 27,42 & 6,00 & 280 & 28,26 & 5,01 & $-1,792$ \\
\hline $\begin{array}{l}\text { VK - seksualne } \\
\text { teme }\end{array}$ & 552 & 20,97 & 8,70 & $5-35$ & 272 & 20,90 & 8,66 & 280 & 21,05 & 8,77 & $-0,203$ \\
\hline $\begin{array}{l}\text { Posredna } \\
\text { komunikacija }\end{array}$ & 551 & 13,56 & 3,03 & $8-26$ & 274 & 13,09 & 3,03 & 277 & 14,03 & 2,95 & $-3,679 * * *$ \\
\hline $\begin{array}{l}\text { Seksualno } \\
\text { ponašanje }\end{array}$ & 557 & 3,18 & 2,18 & $0-7$ & 277 & 2,47 & 1,91 & 280 & 3,89 & 2,20 & $-8,121^{* * *}$ \\
\hline $\begin{array}{l}\text { Bihevioralna } \\
\text { namjera }\end{array}$ & 560 & 3,24 & 1,37 & $1-5$ & 277 & 2,81 & 1,38 & 283 & 3,65 & 1,22 & $-7,629^{* * *}$ \\
\hline Emocije & 530 & 22,08 & 7,82 & $5-35$ & 260 & 19,82 & 7,64 & 270 & 24,24 & 7,38 & $-6,780^{* * *}$ \\
\hline $\begin{array}{l}\text { Dob prvog } \\
\text { spolnog odnosa }\end{array}$ & 176 & 15,45 & 1,09 & & 51 & 14,60 & 0,71 & 125 & 15,80 & 1,03 & $-7,601^{* * *}$ \\
\hline $\begin{array}{l}\text { Broj seksualnih } \\
\text { partnera }\end{array}$ & 172 & 1,97 & 1,69 & & 51 & 1,80 & 1,31 & 121 & 2,04 & 1,83 & $-0,839$ \\
\hline
\end{tabular}

${ }^{*} p<0,05 ;{ }^{* *} p<0,01 ;{ }^{* * *} p<0,001$

\section{Povezanost religioznosti s različitim pokazateljima seksualnog ponašanja i doživljavanja adolescentica}

Većina je pokazatelja seksualnosti djevojaka statistički značajno povezana s ukupnom religioznošću, pri čemu se Pearsonovi koeficijenti korelacije kreću od $-0,08$ do 0,35 za učenice prvog i $-0,20$ do $-0,34$ za učenice trećeg razreda te su u očekivanom smjeru (negativni u svim pokazateljima osim dobi stupanja u spolne odnose) (Tablica 2). Međutim, važno je napomenuti kako su sve navedene korelacije relativno niske. Također, možemo zamijetiti kako su za sve varijable (izuzev dobi stupanja u spolne odnose) veće korelacije za učenice trećih razreda. 


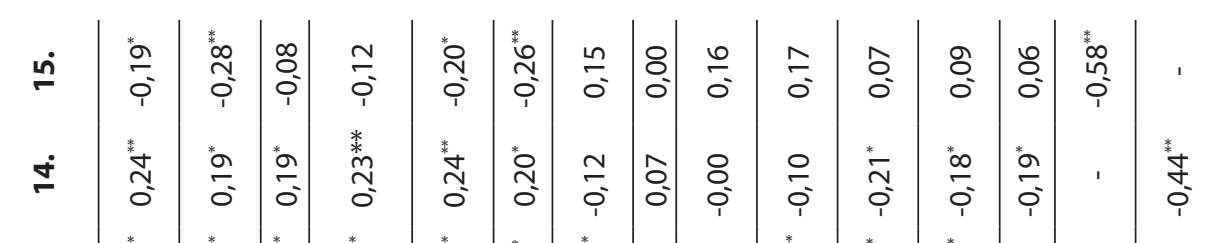

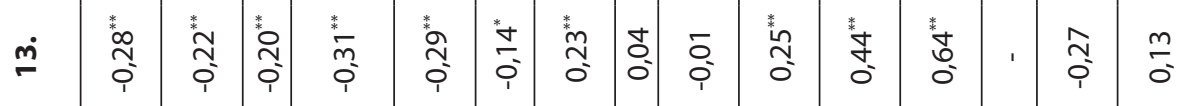

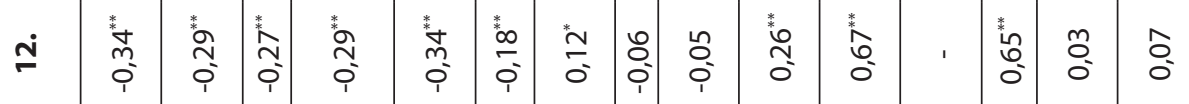

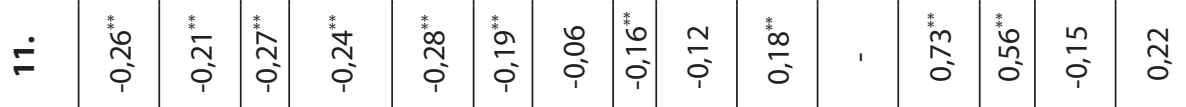

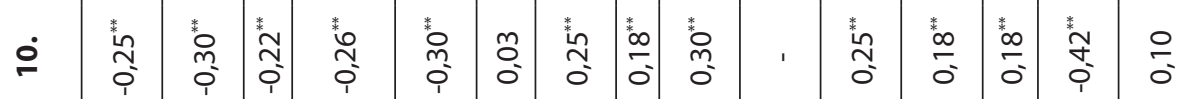

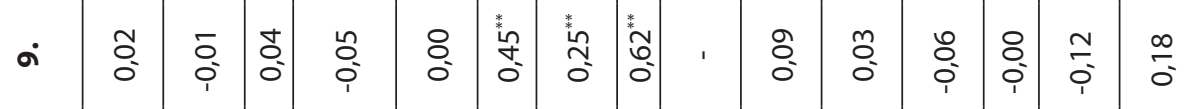

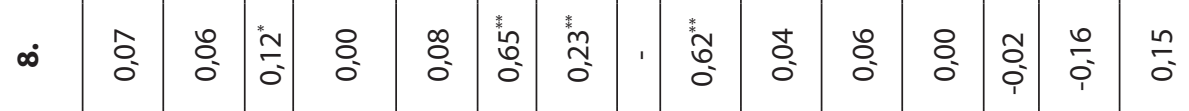

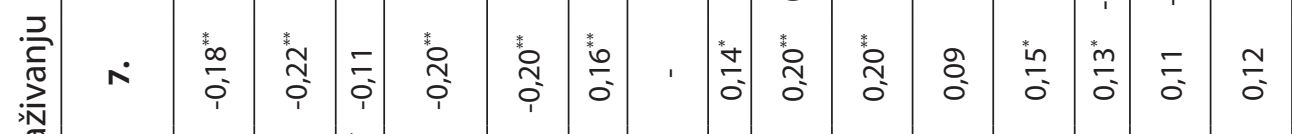

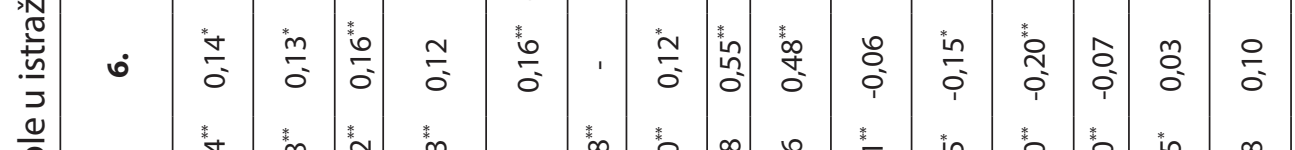

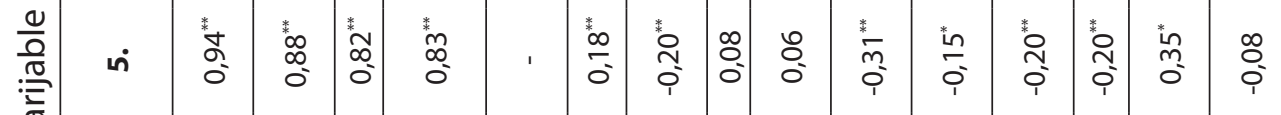

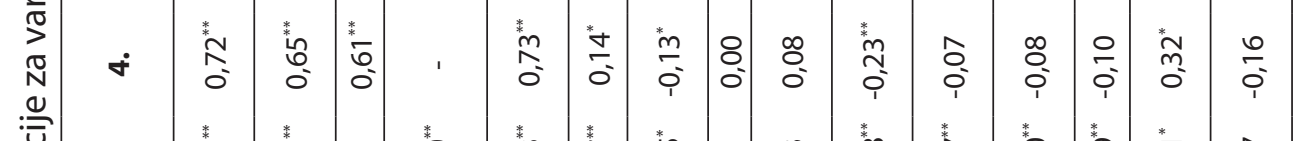

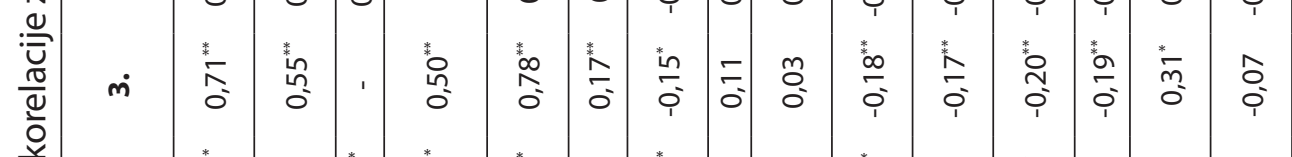

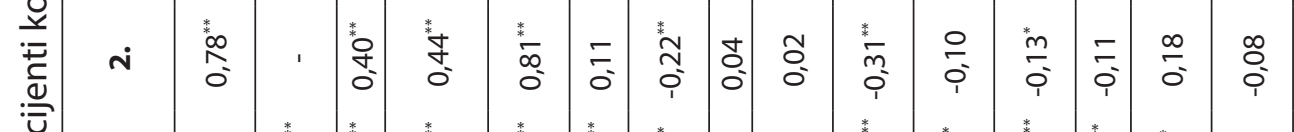

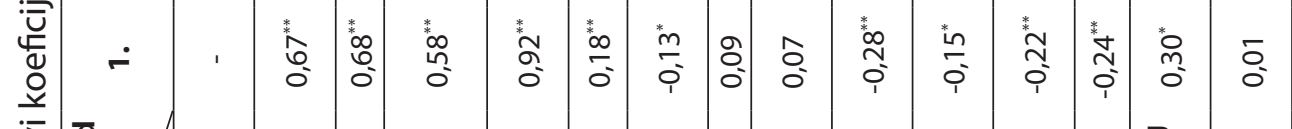

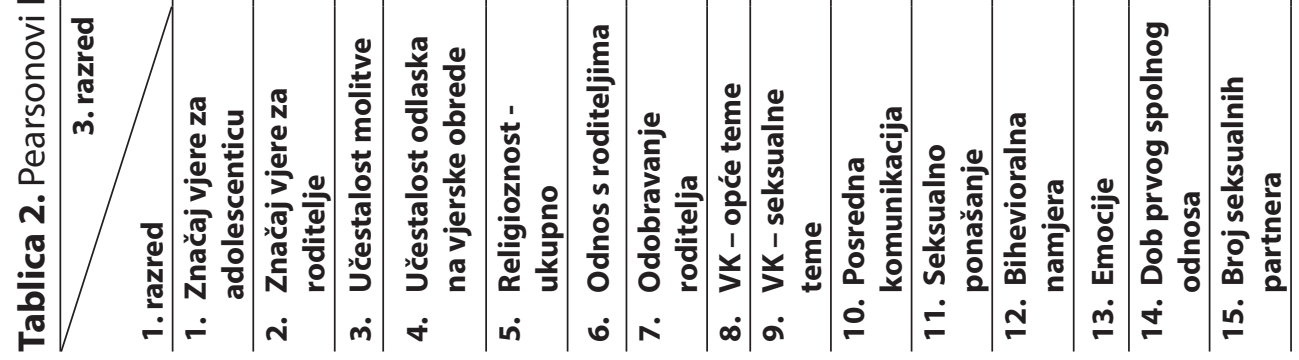


Kako veći broj autora (Burdette i Hill, 2009.; Črpić i Zrinščak, 2010.; Sinha, Cnaan i Gelles, 2007.) upućuje na istraživanje pojedinih aspekata religioznosti, a ne religioznost kao cjeloviti konstrukt, provjerena je povezanost između varijabli seksualnosti i pojedinačnih varijabli religioznosti. Rezultati pokazuju kako su, na uzorku učenica prvog razreda, sve varijable religioznosti najviše povezane s dobi stupanja u prvi spolni odnos (kreću se od 0,18 za važnost vjere za roditelje do 0,32 za učestalost odlaska na vjerske obrede). Također, seksualno ponašanje i motivacija upuštanja u spolne odnose u idućih godinu dana više su povezane s varijablama značaja vjere za sudionicu i učestalosti molitve izvan vjerskog obreda nego s drugim pokazateljima religioznosti. Što se tiče učenica trećih razreda, iste varijable seksualnosti gotovo su podjednako povezane sa svim pokazateljima religioznosti, dok se za broj spolnih partnera izdvaja najviša povezanost s važnosti vjere za roditelje $(r=-0,28)$.

S obzirom na relativno nisku povezanost religioznosti i seksualnosti adolescentica, dodatnim analizama provjerene su razlike između $30 \%$ najmanje religioznih, 30\% najreligioznijih adolescentica te preostalog uzorka (prosječno religiozne srednjoškolke), pri čemu su razmatrani ukupni rezultati na skali religioznosti. U svrhu utvrđivanja razlike u obilježjima seksualnosti između te tri skupine djevojaka provedene su jednostavne analize varijance (s pripadajućim Scheffeovim testovima) (Tablica 3). Što se tiče mlađih učenica, statistički značajni F-omjeri pokazali su se za bihevioralnu namjeru i emocije prema upuštanju u spolne odnose u idućih godinu dana. Pritom najreligioznije djevojke imaju manju namjeru stupanja u spolne odnose od druge dvije skupine djevojaka (koje se međusobno statistički značajno ne razlikuju) te negativnije emocije prema stupanju u spolne odnose od najmanje religioznih djevojaka (preostale komparacije nisu statistički značajne). Nasuprot ovim rezultatima, kod učenica trećih razreda svi su se F-omjeri pokazali statistički značajnima. Najreligioznije djevojke su manje seksualno iskusne, imaju manju namjeru te negativnije emocije prema upuštanju u spolne odnose u idućih godinu dana od prosječno religioznih i 30\% najmanje religioznih djevojaka. Među spolno aktivnim djevojkama, ističu se one najmanje religiozne, koje su ranije stupile u spolne odnose od prosječno religioznih djevojaka te imaju veći broj spolnih partnera od najreligioznijih djevojaka. Preostale razlike između skupina nisu statistički značajne.

\section{6 članci}


Tablica 3. Razlike u pokazateljima seksualnosti između grupa djevojaka ovisno o njihovom stupnju religioznosti

\begin{tabular}{|c|c|c|c|c|c|c|c|c|c|c|c|}
\hline & \multirow[t]{2}{*}{ Varijabla } & \multicolumn{3}{|c|}{$\begin{array}{l}\text { Najmanje } \\
\text { religiozne }\end{array}$} & \multicolumn{3}{|c|}{$\begin{array}{l}\text { Prosječno } \\
\text { religiozne }\end{array}$} & \multicolumn{3}{|c|}{$\begin{array}{c}\text { Najviše } \\
\text { religiozne }\end{array}$} & \multirow[t]{2}{*}{$\mathbf{F}$} \\
\hline & & $\mathbf{N}$ & $M$ & SD & $\mathbf{N}$ & $M$ & SD & $\mathbf{N}$ & $M$ & SD & \\
\hline \multirow{5}{*}{ 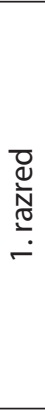 } & $\begin{array}{l}\text { Seksualno } \\
\text { ponašanje }\end{array}$ & 87 & 2,75 & 1,83 & 95 & 2,56 & 2,12 & 95 & 2,13 & 1,73 & 2,578 \\
\hline & $\begin{array}{l}\text { Bihevioralna } \\
\text { namjera }\end{array}$ & 87 & 3,09 & 1,33 & 95 & 2,97 & 1,45 & 95 & 2,40 & 1,28 & $6,883^{* *}$ \\
\hline & Emocije & 80 & 21,38 & 7,50 & 90 & 20,04 & 7,53 & 90 & 18,22 & 7,64 & $3,774^{*}$ \\
\hline & $\begin{array}{l}\text { Dob prvog } \\
\text { spolnog odnosa }\end{array}$ & 20 & 14,45 & 0,51 & 20 & 14,55 & 0,83 & 11 & 14,96 & 0,72 & 1,954 \\
\hline & $\begin{array}{l}\text { Broj seksualnih } \\
\text { partnera }\end{array}$ & 19 & 1,74 & 1,20 & 21 & 1,86 & 1,62 & 11 & 1,82 & 0,87 & 0,041 \\
\hline \multirow{5}{*}{$\begin{array}{l}\text { ర్d } \\
\frac{1}{N} \\
\stackrel{0}{0} \\
\dot{m}\end{array}$} & $\begin{array}{l}\text { Seksualno } \\
\text { ponašanje }\end{array}$ & 86 & 4,61 & 1,88 & 94 & 4,08 & 2,05 & 100 & 3,10 & 2,36 & $12,194^{* * *}$ \\
\hline & $\begin{array}{l}\text { Bihevioralna } \\
\text { namjera }\end{array}$ & 87 & 4,09 & 0,96 & 96 & 3,89 & 1,06 & 100 & 3,05 & 1,34 & $22,442^{* * *}$ \\
\hline & Emocije & 84 & 26,55 & 6,75 & 91 & 25,59 & 6,47 & 95 & 20,92 & 7,60 & $17,122^{* * *}$ \\
\hline & $\begin{array}{l}\text { Dob prvog } \\
\text { spolnog odnosa }\end{array}$ & 49 & 15,47 & 1,19 & 42 & 16,01 & 0,81 & 34 & 16,00 & 0,92 & $4,267^{*}$ \\
\hline & $\begin{array}{l}\text { Broj seksualnih } \\
\text { partnera }\end{array}$ & 48 & 2,58 & 2,44 & 40 & 1,88 & 1,42 & 33 & 1,45 & 0,75 & $4,167^{*}$ \\
\hline
\end{tabular}

${ }^{*} \mathrm{p}<0,05 ;{ }^{* *} \mathrm{p}<0,01 ;{ }^{* * *} \mathrm{p}<0,001$

\section{Provjera posredujućeg učinka roditeljskih varijabli na vezu između religioznosti i seksualnosti adolescenata}

Kako bi se dobio odgovor na drugi problem istraživanja, proveden je niz hijerarhijskih regresijskih analiza, detaljnije opisanih u Obradi podataka. Iz analize su isključene varijable verbalne komunikacije između roditelja i adolescenata, za koje se nije utvrdila statistički značajna povezanost s religioznošću djevojaka (Tablica 2). Također, važno je spomenuti da su za tri šire varijable seksualnosti (seksualno ponašanje, namjeru i emocije) analize provedene na cijelim subuzorcima učenica prvih i trećih razreda, bez obzira jesu li one seksualno aktivne ili nisu. Rezultati hijerarhijskih regresijskih analiza prikazani su u Tablici 4. 


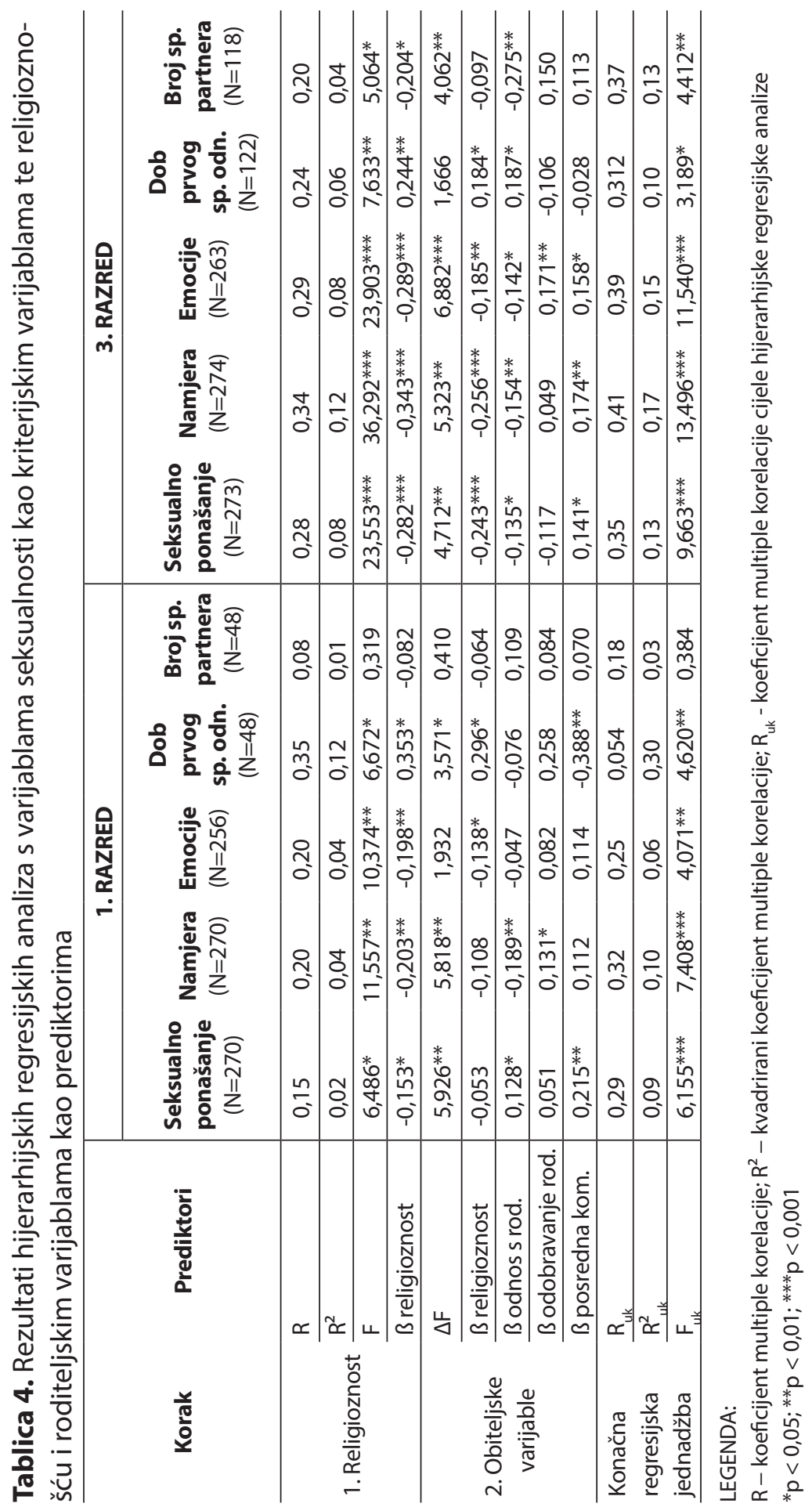


Iz prikazanog se vidi kako prilikom predviđanja emocija prema upuštanju u spolne odnose u idućih godinu dana te broja spolnih partnera kod mlađih djevojaka nema osnove za provjeravanje medijacijskih učinaka. Također, u svim se HRA regresijski koeficijent za varijablu religioznosti smanjio u drugom koraku, iako u većini slučajeva i dalje ostaje statistički značajan (i direktno je i indirektno povezana sa seksualnošću djevojaka). Naknadne analize potencijalno značajnih posredujućih varijabli, provedene računanjem pojedinih regresijskih analiza i Sobel testa, pokazale su kako, kod učenica prvih razreda, odnos s roditeljima posreduje u vezi religioznosti i namjeri upuštanja u spolne odnose u idućih godinu dana $(z=-2,060, p<0,05)$. Također, posredna komunikacija o seksualnosti pokazala se kao značajan medijator između religioznosti i tri pokazatelja seksualnosti djevojaka - seksualnog ponašanja $(z=-3,000, p<0,01)$, bihevioralne namjere $(z=-2,013, p<0,05)$ te dobi stupanja $u$ spolne odnose seksualno aktivnih djevojaka $(z=2,350, p<0,05)$. Što se tiče starijih učenica, vezu između religioznosti i misli i osjećaja te upuštanja u spolne odnose u idućih godinu dana posreduju odobravanje seksualnog ponašanja adolescentice od strane roditelja $(z=-2,235, p<0,05)$ te posredna komunikacija o seksualnosti $(z$ $=-2,566, p<0,01)$, a posredna komunikacija je značajan medijator i u vezi religioznosti i namjere stupanja u spolne odnose $(z=-2,564, p<0,01)$.

\section{RASPRAVA}

Rezultati provedenog istraživanja ukazuju na prilično veliku seksualnu aktivnost srednjoškolki Grada Zagreba i Zagrebačke županije, pri čemu je trećina učenica imala vaginalni spolni odnos barem jednom u životu, dok je među učenicama trećih razreda seksualno aktivna gotovo svaka druga djevojka. Takvi rezultati su ili u skladu ili nešto viši od pokazatelja dosadašnjih istraživanja provedenim u $\mathrm{Hr}$ vatskoj (Ajduković, Ručević i Šincek, 2008.; Dabo i sur., 2008.; Hodžić i Bijelić, 2003.; Kuzman i sur., 2007.). Međutim, viši udio seksualno aktivnih djevojaka dobio je Bezinović (2013.), u čijem istraživanju provedenom u Primorsko-goranskoj, Istarskoj i Dubrovačko-neretvanskoj županiji preko $50 \%$ srednjoškolki starijih od 16 godina ima iskustvo spolnog odnosa.

Kada je riječ o povezanosti seksualnosti s religioznošću djevojaka, u skladu s ostalim istraživanjima (npr. Burdette i Hill, 2009.; Haglund i Fehring, 2010.; Hull i sur., 2011.), dobivaju se značajne negativne korelacije (što su djevojke religioznije imaju manje seksualnog iskustva i manju motivaciju upuštanja u spolne odnose u idućih godinu dana). Međutim, te su korelacije prilično niske, što se dijelom može objasniti time da se prosječno religiozne i najmanje religiozne djevojke u većini pokazatelja seksualnosti ne razlikuju značajno, dok se izdvajaju upravo najreligioznije djevojke po tome što imaju manje seksualnog iskustva, kasnije stupaju u spolne 
odnose, imaju manju motivaciju upuštanja u spolne odnose te imaju manji broj seksualnih partnera. Moguće je da se kod najreligioznijih djevojaka radi o intrinzičnoj religioznosti. $U$ istraživanju se pokazalo i to da je kod mlađih djevojaka seksualno ponašanje i motivacija upuštanja u spolne odnose u idućih godinu dana značajno više povezana s varijablama značaja vjere za sudionicu i učestalosti molitve izvan vjerskog obreda nego s drugim pokazateljima religioznosti. Upravo su te varijable svojevrsni pokazatelji intrinzične religioznosti jer se odnose na privatnu posvećenost vjeri, koja nije očita izvana, pa osoba nema motivaciju »činiti to« kako bi osigurala određeni status u društvu ili se deklarirala religioznom iako svoju vjeru nije zaista internalizirala. Dodatne analize kojima se uzorak podijelio na osnovu upravo te dvije tvrdnje potvrdile su ovu hipotezu. Naime, u najreligioznijoj skupini adolescentica upravo je $93 \%$ onih koje postižu najviše rezultate na intrinzičnoj religioznosti.

U svim varijablama (izuzev dobi stupanja u spolne odnose) veće korelacije između seksualnosti i religioznosti te veće razlike između najreligioznijih, prosječno religioznih i najmanje religioznih djevojaka dobivaju se za učenice trećih razreda. Takav rezultat u skladu je $s$ dosadašnjim istraživanjima koja naglašavaju da je privatna religioznost precizniji indikator religioznosti za starije nego za mlađe adolescente (Burdette i Hill, 2009.). Zanimljivo je da su kod mlađih djevojaka sve varijable religioznosti najviše povezane s dobi stupanja u prvi spolni odnos, a između grupa djevojaka koje se razlikuju po stupnju religioznosti nema statistički značajnih razlika u seksualnom iskustvu, ali ima u motivaciji stupanja u spolne odnose (najreligioznije djevojke imaju manju namjeru stupanja u spolne odnose te negativnije emocije prema istom od druge dvije skupine djevojaka). Ovi rezultati u skladu su s istraživanjem Hull i sur. (2011.), u kojem se pokazalo kako religioznost ne pridonosi predviđanju seksualnog ponašanja adolescenata povrh prediktora namjere stupanja u spolne odnose i stavova prema istom, već pohađanje vjerskih obreda preko tih varijabli djeluje na seksualno ponašanje. Također, Vasilenko i sur. (2013.) navode kako kod studenata motivacija posreduje odnos između religioznosti i seksualnog ponašanja, odnosno religiozni studenti internaliziraju norme o seksualnom ponašanju i ponašaju se u skladu s njima.

Rezultati pokazuju kako je značajan medijator u većem broju veza između religioznosti i seksualnosti, i kod mlađih i kod starijih adolescentica, posredna komunikacija roditelja o seksualnosti. lako je većina autora našla da je bliskost roditelja i djeteta kombinirana s otvorenom, pozitivnom i učestalom komunikacijom o seksu povezana s apstinencijom adolescenta, odgađanjem prvog spolnog odnosa, imanjem manjeg broja seksualnih partnera te dosljednijom uporabom kontracepcije (Hutchinson i sur., 2003.; Karofsky, Zeng i Kosovok, 2001.; Miller, Benson i Galbraith, 2001.), u ovom istraživanju se značajnom nije pokazala verbalna, već posredna komunikacija o seksualnosti. Pritom je posredna komunikacija negativno povezana

\section{0 članci}


$s$ religioznošću i pozitivno sa seksualnim ponašanjem i motivacijom upuštanja u spolne odnose. Moguće je da su roditelji djece koja odrastaju u religioznim obiteljima i internaliziraju religijske vrijednosti manje seksualno ekspresivni i prema seksualnosti se ne odnose »otvoreno " pa i njihove kćeri imaju manju namjeru stupanja u spolne odnose, negativnije emocije prema tome te u konačnosti imaju i manje seksualnog iskustva. Joffe i Franca-Koh (2001.) svojim su istraživanjem pokazali kako ranije u spolne odnose stupaju adolescenti kojima su roditelji pružali otvoreniju neverbalnu komunikaciju o seksualnosti. Zanimljivo je kako u ovom istraživanju posredna komunikacija roditelja s adolescenticom o seksualnosti nije povezana s verbalnom komunikacijom o seksualnim temama. Jedna hipoteza može biti da roditelji zapravo nisu svjesni svojih posrednih poruka koje djeci šalju, a istovremeno u verbalnu komunikaciju ulažu svjestan napor pa se ta dva načina komunikacije odvijaju u posve različitom modalitetu i na različit način, koji može, a i ne mora, adolescentu slati usklađene poruke.

Što se tiče drugih roditeljskih varijabli kao medijatora, religioznost mlađih djevojaka je preko boljeg odnosa s roditeljima povezana s manjom namjerom upuštanja u spolne odnose u idućih godinu dana, dok religioznije učenice trećeg razreda imaju roditelje koji većinom ne odobravaju njihovo seksualno ponašanje te i one same imaju negativnije misli i osjećaje prema upuštanju u spolne odnose. Prema Manlove i sur. (2008.), visoka obiteljska religioznost može omogućiti pozitivno obiteljsko funkcioniranje i kohezivnost jer članovi obitelji često zajedno odlaze na religijske obrede i sudjeluju u religioznim aktivnostima. Prema tome, viša obiteljska religioznost može promicati pozitivan odnos između roditelja i djeteta tako što omogućava roditeljima i djeci da zajedno provode vrijeme u podržavajućem okruženju, koje smanjuje vjerojatnost da će adolescent imati spolne odnose (Manlove i sur., 2008.). Nadalje, djeca u religioznim obiteljima u doticaju su sa socijalnom mrežom prijatelja i obitelji koje su također religiozne te se druže s religioznim vršnjacima koji mogu zastupati moralna pravila koja ne podržavaju seksualna ponašanja izvan braka (Holder i sur., 2000.).

lako prikazani nalazi prate dosadašnje spoznaje, potrebno ih je razmatrati pod vidom ograničenja provedenog istraživanja. Kao što je već navedeno, kako ovdje nije riječ o longitudinalnom (niti eksperimentalnom) nacrtu, ne možemo govoriti o uzročno-posljedičnim vezama između pojedinih varijabli, već samo o njihovoj povezanosti. Nadalje, usprkos slučajnom uzorkovanju, uzorak koji je korišten u ovom istraživanju nije u potpunosti reprezentativan za populaciju srednjoškolki Grada Zagreba i Zagrebačke županije. Naime, u istraživanju su sudjelovale učenice strukovnih škola u kojima prevladavaju djevojke (preko 50\%), odnosno za koje se može reći da su »ženske škole«. Osim što se tako ne dobiva stvarna slika o seksualnosti svih djevojaka koje se školuju na navedenom području Hrvatske, može se pretpostaviti da se djevojke odabranih strukovnih škola po brojnim karakteristikama 
(uključivši seksualno ponašanje) razlikuju od djevojaka koje pohađaju tzv. »muške škole« (na primjer, strojarske, informatičke, tehničke škole). Kada je, pak, riječ o instrumentariju, skraćivanje skale u SDQ-II sa šest na četiri stupnja, iako je pridonijelo pojednostavljivanju upitnika, smanjilo je njegovu diskriminativnost. Što se tiče mjerenja komunikacije adolescentice $s$ roditeljima, iako su prilikom ispitivanja verbalne komunikacije u obzir uzete različite dimenzije komunikacije te različite teme, nedostatak je što se sudionice nije tražilo da odgovore daju s obzirom na komunikaciju koja se odvijala u proteklih godinu dana, a ne ikada u životu. Konačno, u ovom istraživanju je konstrukt religioznosti mjeren sa samo četiri varijable te bi se u budućim istraživanjima trebala zahvatiti šira operacionalizacija religioznosti, kao i jasno raščlaniti mjeri li se pojedinom česticom ili subskalom intrinzična ili ekstrinzična religioznost.

Unatoč navedenim ograničenjima, rezultati provedenog istraživanja ukazali su kako povezanost religioznosti i seksualnosti djevojaka nije jednostavna, već ovisi kako o dobi mlade osobe, obliku i internaliziranosti religioznosti, tako i o kontekstu koji povezuje ta dva fenomena, kao što je obiteljski kontekst. Pritom je naročito važan odnos koji roditelji ostvaruju s djecom te koje im vrijednosti vezano za seksualnost, i na koji način, prenose.

\section{ZAKLJUČAK}

U radu opisano istraživanje pokazalo je kako je religioznost djevojaka značajno povezana s njihovim seksualnim ponašanjem i doživljavanjem, pri čemu se najreligioznije djevojke, u odnosu na prosječno i najmanje religiozne, ističu manjim seksualnim iskustvom te manjom motivacijom upuštanja u spolne odnose $u$ neposrednoj budućnosti. Povezanost religioznosti i seksualnosti je veća kod starijih adolescentica, pri čemu su religiozne djevojke vjerojatno internalizirale svoju vjeru i više žive u skladu s vjerskim doktrinama. Također, pokazalo se kako su i kod mlađih i kod starijih adolescentica posredne poruke koje im roditelji šalju o seksualnosti značajan medijator u vezi između religioznosti i seksualnosti, pri čemu je posredna komunikacija negativno povezana s religioznošću i pozitivno sa seksualnim ponašanjem i motivacijom upuštanja u spolne odnose. Kod učenica prvih razreda srednje škole u toj je vezi značajan medijator i odnos s roditeljima, dok je kod učenica trećih razreda to slučaj za odobravanje seksualnog ponašanja adolescentice od strane roditelja.

\section{2 članci}




\section{LITERATURA}

1. Ajduković, M., Ručević, S. \& Šincek, D. (2008). Istraživanje rasprostranjenosti rizičnog i delinkventnog ponašanja djece i mladih u urbanim sredinamadodatni poticaj za ciljanu prevenciju. Dijete i društvo, 10 (1-2), 27-47.

2. Aron, A.\& Aron, E. N. (1994). Statistics for psychology. New Jersey, Englewood Cliffs: Prentice Hall.

3. Baron, R. M. \& Kenny, D. A. (1986). The moderator-mediator variable distinction in social psychological research: Conceptual, strategic, and statistical considerations. Journal of Personality and Social Psychology, 51 (6), 1173-1182.

4. Bernik, I. \& Hlebec, V. (2005). How did it happen the first time? Sexual initiation of secondary school students in seven postsocialist countries. In: Štulhofer, A. \& Sandfort, T. (eds.), Sexuality and gender in postcommunist Eastern Europe and Russia. New York: Haworth Press, 297-315.

5. Bezinović, P. (2013). Religioznost, seksualnost i rodne razlike u zadovoljstvu životom adolescenata. 21. dani Ramira i Zorana Bujasa - Sažeci priopćenja. Zagreb: Filozofski fakultet, 121.

6. Božičević, I., Štulhofer, A., Ajduković, D. \& Kufrin, K. (2006). Patterns of sexual behaviour and reported symptoms of sti/rtis among young people in Croatia - Implications for interventions' planning. Collegium Antropologicum, 30 (2), 63-70.

7. Burdette, A. M. \& Hill, T. D. (2009). Religious involvement and transitions into adolescent sexual activities. Sociology of Religion, 70 (1), 28-48.

8. Centers for Disease Control and Prevention (2014). Youth risk behavior surveillance - United States, 2013. Surveillance Summaries, MMWR, 63 (4), 1-168.

9. Črpić, G. \& Zrinščak, S. (2010). Dinamičnost u stabilnosti: Religioznost u Hrvatskoj 1999. i 2008. godine. Društvena istraživanja, 19 (1-2), 3-27.

10. Dabo, J., Malatestinić, Đ., Janković, S., Bolf Malović, M. \& Kosanović, V. (2008). Zaštita reproduktivnog zdravlja mladih - modeli prevencije. Medicina Fluminensis, 44 (1), 72-79.

11. Dijanić, T., Kožul, K., Miškulin, M,. Medić, A., Jurčev-Savičević, A. \& Burazin, J. (2014). Sexual behaviour and condom use as a protection against sexually transmitted infections in student population. Collegium Antropologicom, 38 (1), 31-37.

12. Etički kodeks istraživanja s djecom (2003). Zagreb: Vijeće za djecu Vlade RH, Državni zavod za zaštitu obitelji, materinstva i mladeži.

13. Graber, J. A. \& Sontag, L. M. (2006). Puberty and girls' sexuality: Why hormones are not the complete answer. New Directions for Child i Adolescent Development, 112 (1), 23-38. 
14. Haglund, K. A. \& Fehring, R. J. (2010). The association of religiosity, sexual education and parental factors with risky sexual behaviors among adolescents and young adults. Journal of Religion and Health, 49 (4), 460-472.

15. Halpern-Felsher, B. L., Cornell, J. L., Kropp, R. Y. \& Tschann, J. M. (2005). Oral versus vaginal sex among adolescents: Perceptions, attitudes, and behavior. Pediatrics, 115 (4), 845-851.

16. Hennessy, M., Bleakley, A., Fishbein, M. \& Jordan, A. (2008). Validating an Index of adolescent sexual behavior using psychosocial theory and social trait correlates. AIDS and behavior, 12 (2), 321-331.

17. Hodžić, A. \& Bijelić, N. (2003). Značaj roda u stavovima i seksualnom ponašanju adolescenata i adolescentica: Izvještaj istraživanja »Muškarci, žene, i seksualnost $\lll$. Zagreb: CESI.

18. Holder, D. W., Durant, R. H., Harris, T. L., Henderson D. J., Obeidallah, D. I. \& Goodman, E. (2000). The association between adolescent spirituality and voluntary sexual activity. The Journal of Adolescent Health, 26 (4), 295-302.

19. Hull, S. J., Hennessy, M., Bleakley, A., Fishbein, M. \& Jordan, A. (2011). Identifying the causal pathways from religiosity to delayed adolescent sexual behavior. Journal of Sex Research, 48 (6), 543-553.

20. Hutchinson, M. K., Jemmott, J. B., Jemmott, L. S., Braverman, P. \& Fong, G. T. (2003). The role of mother-daughter sexual risk communication in reducing sexual risk behaviors among urban adolescent females: A prospective study. Journal of Adolescent Health, 33 (2), 98-107.

21. Joffe, H. \& Franca-Koh, A. C. (2001). Parental non-verbal sexual communication: Its relationship to sexual behaviour and sexual guilt. Journal of Health Psychology, 6 (1), 17-30.

22. Karofsky, P., Zeng, L. \& Kosovok, M. (2001). Relationship between adolescentparental communication and initiation of first intercourse by adolescents. Journal of Adolescent Health, 28 (1), 41-45.

23. Kirby, D. \& Lepore, G. (2007). Sexual risk and protective factors: Factors affecting teen sexual behavior, pregnancy, childbearing, and sexually transmitted disease: Which are important? Which can You change? Washington, DC: National Campaign to Prevent Teen Pregnancy.

24. Krauss, H.,Bogdański,P.,Szulińska,M.,Malewski,M.,Buraczyńska-Andrzejewska, B., Sosnowski, P., Piątek, J., Demont, C., Kaczmarek, C., Kaczmarek, E., Szpakow, A., Kleszczewska, E., Maciorkowska, E., Klimberg, A. J. \& Mikrut, K. (2012). Sexual initiation of youths in selected European countries compared with their sexual and contraceptive knowledge. Annals of Agricultural and Environmental Medicine, 19 (3), 587-592.

25. Kuzman, M., Pavić Šimetin, I. \& Pejnović Franelić, I. (2007). Early sexual intercourse and risk factors in Croatian adolescents. Collegium Antropologicum, 31 (2), 121-130. 
26. Landor, A., Simons, L. G., Simons, R. L., Brody, G. H. \& Gibbons, F. X. (2011). The role of religiosity in the relationship between parents, peers and adolescent risky sexual behavior. Journal of Youth and Adolescence, 40 (3), 296-309.

27. Manlove, J., Logan, C., Moore, K. A. \& Ikramullah, E. (2008). Pathways from family religiosity to adolescent sexual activity and contraceptive use. Perspectives on Sexual i Reproductive Health, 40 (2), 105-117.

28. Manlove, J. S., Terry-Humen, E., Ikramullah, E. N. \& Moore, K. A. (2006). The role of parent religiosity in teens' transitions to sex and contraception. The Journal of Adolescent Health, 39 (4), 578-587.

29. Marsh, H. W. (1992). Self Description Questionnaire (SDQ) II: A theoretical and empirical basis for the measurement of multiple dimensions of adolescent self-concept. A test manual and research monograph. Macarthur, New South Wales, Australia: University of Western Sydney, Faculty of Education.

30. Miller, B. C., Benson, B. \& Galbraith, K. A. (2001). Family relationships and adolescent pregnancy risk: A research synthesis. Developmental Review, 21 (1), 1-38.

31. Preacher, K. J. \& Leonardelli, G. J. (2003). Calculation for the Sobel test: An interactive calculation tool for mediation tests. Preuzeto s: http:// quantpsy.org/sobel/sobel.htm (20.12.2014.)

32. Rajhvajn Bulat, L. (2011). Okolinske i osobne odrednice seksualnog ponašanja adolescentica. (Neobjavljena doktorska disertacija). Zagreb: Filozofski fakultet.

33. Ross, J., Godeau, E. \& Dias, S. (2004). Sexual health. In: Currie, C., Roberts, C., Morgan, A., Smith, R., Settertobulte, W., Samdal, O. \& Barnekow Rasmussen, V. (eds.), Young people's health in context. Health behaviour in school-aged children (HBSC) study: International report from the 2001/2002 survey. Copenhagen: WHO.

34. Rostosky, S. S., Regnerus, M. D. \& Wright, M. L. (2003). Coital debut: The role of religiosity and sex attitudes in the Add Health Survey. Journal of Sex Research, 40 (4), 358-367.

35. Schuster, M. A., Bell, R. M. \& Kanouse, D. E. (1996). The sexual practices of adolescent virgins: Genital sexual activities of high school students who have never had vaginal intercourse. American Journal of Public Health, 86 (11), 1570-1576.

36. Sinha, J. W., Cnaan, R. A. \& Gelles, R. J. (2007). Adolescent risk behaviors and religion: Findings from a national study. Journal of Adolescence, 30 (2), 231-249.

37. Tabachnick, B. G. \& Fidell, L. S. (1989). Using multivariate statistics. New York: Harper Collins. 
38. Treboux, D. \& Busch-Rossnagel, N. A. (1990). The parental and friends' approval of sexual behavior scale - PASB, FASB. In: Touliatos, J., Perlmutter, B. F. \& Holden, G.W. (eds.), (2001). Handbook of family measurement techniques: Instruments i indeks. London: Sage Publications Ltd., 77-79.

39. Vasilenko, S. A., Duntzee, C. I., Zheng, Y. \& Lefkowitz, E. S. (2013). Testing two process models of religiosity and sexual behavior. Journal of Adolescence, 36 (4), 667-673.

40. Vranješ, H., Džepina, M. \& Juhović Markus, V. (2011). Reproductive health state of adolescents and connection with some life habits. Paediatria Croatica, 55 (3), 197-203.

41. World Health Organization (2004). Sexual health: A new focus for WHO. Progress in Reproductive Health Research, 67, 1-8.

Linda Rajhvajn Bulat

University of Zagreb

Faculty of Law

Department of Social Work

\title{
RELATIONSHIP BETWEEN RELIGIOUSNESS AND SEXUALITY IN FEMALE ADOLESCENTS - DO PARENTS HAVE A MEDIATING ROLE?
}

\begin{abstract}
The aim of this paper is to examine the relationship between the religiousness of female adolescents and their sexual behaviour and experience, as well as the role that this connection has in the girls' relationships and communication with their parents.

A total of 560 female secondary school students in the $1^{\text {st }}$ and $3^{\text {rd }}$ grades from Zagreb and the Zagreb County participated in the research. The variables pertinent to this research were measured with the Sexuality Questionnaire (sexual behaviour, intention to engage in sexual activities in the next year, thoughts and feelings about engaging in sexual activities in this period), claims referring to the religiousness of the participants, the Relationship with Parents subscale from Marsh's Self Description Questionnaire II, the Scale of parental and peer approval of sexual behaviour, and the Questionnaire on the communication of adolescents with parents.

The results confirm that there is a strong connection between the female adolescents' religiousness and their sexual behaviour and experience, with the most religious female adolescents having less sexual experience and being less motivated to engage in sexual activities in the next twelve months. The connection between religiousness and sexuality is stronger in older adolescents. In addition, a significant mediator in the connection between the girls' religiousness and sexuality are indirect messages regarding sexuality that they receive from their parents. For 1st grade students, a significant mediator in this connection is their relationship with their parents, whereas for 3rd grade students it is the parents' approval of their sexual behaviour.
\end{abstract}

Key words: female adolescents, sexual behaviour, religiousness, parents, communication. 